\title{
ASSOCIATIONS OF DURATION OF EXPOSURE AND YEARS OF SERVICE WITH TRANS-TRANS MUCONIC ACID LEVEL AMONG PRINTING INDUSTRY WORKERS IN MEDAN, NORTH SUMATERA
}

\author{
Annisa Febriana Siregar, Taufik Ashar, Nurmaini \\ Department of Environmental Health, Faculty of Public Health, \\ Universitas Sumatera Utara
}

\begin{abstract}
Background: Trans, trans-Muconic acid is a metabolite of benzene in humans. The determination of its concentration in urine is used as a biomarker of occupational or environmental exposure to benzene. Benzene, also known as benzol, is a colorless liquid with a sweet odor. Benzene evaporates into air very quickly and dissolves slightly in water. Benzene is used in various industries incuding printing industry to make other chemicals. Benzene in the eyes may cause general irritation and damage to cornea. People who breathe benzene for long periods may experience harmful effects in the tissues that form blood cells, especially the bone marrow. This study aimed to analyze the associations of duration of exposure and years of service with trans-trans muconic acid level among printing industry workers in Medan, North Sumatera.

Subjects and Method: This was a cross sectional study carried out at printing industry in Medan, North Sumatera. A sample of 16 printing workers were selected for this study. The dependent variable was trans-trans muconic acid level. The independent variables were age, sex, duration of exposure, and years of service. The data were collected by questionnaire and analyzed by a multiple linear regression.

Results: The associations of age and sex with trans-trans muconic acid was stastically non-significant. The associations of duration of exposure and years of service with trans-trans muconic acid were stastically significant. The longer duration of exposure and the longer years of service, the higher trans-trans muconic acid level indicating the higher benzene level.

Conclusion: Trans-trans muconic acid level is associated with duration of exposure and years of service.
\end{abstract}

Keywords: age, sex, duration of exposure, years of service, trans-trans muconic acid

\section{Correspondence:}

Annisa Febriana Siregar. Department of Environmental Health, Faculty of Public Health, Universitas Sumatera Utara, Medan, North Sumatera.

Email: nsafbrn@gmail.com. Mobile: +6282277975080. 